\title{
American eel, Anguilla rostrata, growth in fresh and salt water: implications for conservation and aquaculture
}

\author{
H. M. LAMSON \\ Biology Department, University of New Brunswick, Fredericton, New Brunswick, Canada
}

D. K. CAIRNS

Department of Fisheries and Oceans, Charlottetown, Prince Edward Island, Canada

J.-C. SHIAO

Institute of Oceanography, College of Science, National Taiwan University, Taipei, Taiwan, Republic of China

\section{Y. IIZUKA}

Institute of Earth Sciences, Academia Sinica, Nankang, Taipei, Taiwan, Republic of China

\author{
W. - N. TZENG \\ Institute of Fisheries Sciences, National Taiwan University, Taipei, Taiwan, Republic of China
}

\begin{abstract}
Growth of American eels, Anguilla rostrata (Lesueur), sampled in saltwater bays and adjacent freshwater ponds in the southern Gulf of St. Lawrence, Canada, was estimated by otolith annulus back-calculation, and related to salinity of growth habitat as determined using otolith strontium:calcium ratios. Eels resident in salt water grew on average in length 2.2 times faster than freshwater residents and increased in weight 5.3 times faster than freshwater residents. Previous findings of superior American eel growth rate in brackish water are thus extended to full-strength salt water. Freshwater residents took an estimated 2.4 times longer than saltwater residents to reach the silver eel stage. The extended time to maturation of eels reared in fresh water increases their vulnerability to fisheries and to bio-accumulation of contaminants. Freshwater eel populations should be managed more conservatively than those in saline waters. The increase in eel growth with salinity suggests that rearing in brackish or salt water could improve growth rates in eel aquaculture.
\end{abstract}

KEYWORDS: Anguilla, growth, otoliths, strontium:calcium.

\section{Introduction}

Growth is a key factor in fish demographics and life history. Anguillid eels spawn in ocean basins but accomplish nearly all of their growth in continental waters (Tesch 2003). Most fish grow throughout their lives, albeit more slowly after onset of sexual maturity (Pitcher \& Hart 1982). By contrast, anguillid eels grow to a threshold size that is specific to sex and local subpopulation; they then mature, spawn and die (De Leo \& Gatto 1995; Holmgren, Wickstrom \& Clevestam 1997). Thus the major consequence of growth performance is 
not the maximum size attained, but rather the time required to reach the single reproductive event.

Anguillid eels are traditionally viewed as freshwater inhabitants during their continental phase, but many (perhaps most) continental-phase eels occupy saline (brackish or salt) habitats that are typically sheltered bays and estuaries (Moriarty 2003). Strontium:calcium life-history studies (Tzeng, Severin \& Wickstrom 1997) have found that some eels in continental waters are residents of salt or brackish water, some are freshwater residents, and some shift once or multiple times between salinity zones (Daverat, Limburg, Thibault, Shiao, Dodson, Caron, Tzeng, Iizuku and Wickstrom 2006; Lamson, Shiao, Iizuka, Tzeng \& Cairns 2006; Jessop, Cairns, Thibault \& Tzeng 2008).

Because of facultative movements between salinity zones, the habitat of eels at the yellow stage does not reliably indicate where previous growth has accrued. Hence habitat-specific growth rates in eels are best determined when location of growth is confirmed by the otolith $\mathrm{Sr}$ :Ca method. Such investigations found higher growth rates in brackish water than adjacent freshwater in American (Anguilla rostrata, Lesueur; Cairns, Shiao, Iizuka, Tzeng \& MacPherson 2004; Jessop, Shiao, Iizuka \& Tzeng 2004; Thibault, Dodson, Caron, Tzeng, Iizuka \& Shiao 2007), European ( $A$. anguilla, L., Daverat \& Tomas 2006) and Japanese eels (A. japonica, Temminck and Schlegel; Tzeng, Iizuka, Shiao, Yamada \& Oka 2003).

Steep declines in some population indices have prompted widespread concern about the conservation of anguillid eels (Dekker, Casselman, Cairns, Tsukamoto, Jellyman \& Lickers 2003), including American eels (Richkus \& Whalen 2000; Casselman 2003). Most eel fisheries in eastern North America are prosecuted in coastal bays and estuaries (Jessop 1997), but the majority of biological data on the species were collected in fresh water. Temperate-zone anguillid eels reared in fresh water may suffer a fitness disadvantage because of their slow growth (Cairns et al. 2009). Morrison \& Secor (2003) argued that eel conservation measures should consider growth and productivity differences between brackish and fresh rearing areas, leading to management regimes that are specific to salinity zones. This has not been possible for American eels that rear in salt water because of a lack of growth data for this habitat.

The eel aquaculture industry uses wild-caught glass eels to stock eel farms that are chiefly located in Asia (mainly China, Taiwan, and Japan) and Europe (mainly the Netherlands and Italy) (Lee, Chen, Lee $\&$ Liao 2003). Growth rate is a key factor in aquaculture because it determines the time required by the fish to reach market size. Farmed eels are reared in fresh or nearly fresh water, but salinity-based growth differentials seen in wild eels suggest that growing in saline waters might improve weight gain, thereby speeding the production cycle and reducing resource requirements.

This study determined growth parameters of American eels whose previous continental residency was in salt water, fresh water, or both, through otolith $\mathrm{Sr}: \mathrm{Ca}$ analysis (Lamson et al. 2006). These growth rates were used to examine implications for salinity-specific conservation management, and for the productivity and environmental impact of eel aquaculture.

\section{Methods}

This study was conducted on the north shore of Prince Edward Island in the southern Gulf of St. Lawrence, Canada (Fig. 1). Brackley and Covehead Bays contain full-strength salt water ( $>28 \mathrm{ppt}$ ) and receive drainage from a watershed of $81 \mathrm{~km}^{2}$. Freshwater impoundments, formed by dams, drain directly into these bays. Water exits McCallums Pond to Brackley Bay by falling vertically $2.2 \mathrm{~m}$ from a wooden spillway set in an earthen dam. Cass Pond drains to Covehead Bay via a $5 \mathrm{~m}$ wide vertical concrete spillway, and a fivechamber pool-and-weir salmonid fishway through which water drops $0.9 \mathrm{~m}$ over a horizontal distance of $12.2 \mathrm{~m}$. Marshalls Pond drains into Covehead Bay by a low-gradient channel with a rocky bottom that falls $5.0 \mathrm{~m}$ over a horizontal distance of $303 \mathrm{~m}$.

Fyke nets, baited pots and backpack electrofishing were used to capture eels in May-November 2003. Eels were anaesthetised with clove oil $(0.1 \mathrm{~mL}$ of clove oil per $1 \mathrm{~mL}$ of ethanol per $2 \mathrm{~L}$ of water), measured for total length (to $1 \mathrm{~mm}$ ), weighed (to $1 \mathrm{~g}$ ) and frozen until the otoliths were removed.

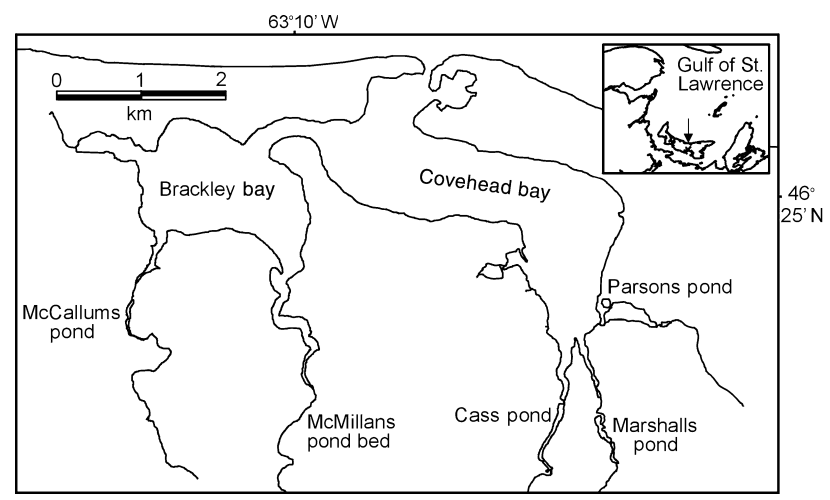

Figure 1. Brackley and Covehead Bays, Prince Edward Island, and associated freshwater ponds. 
Salinity histories of 95 eels were inferred from otolith $\mathrm{Sr}: \mathrm{Ca}$ transects. Sr:Ca ratio was measured at $10 \mu \mathrm{m}$ increments along the radius of the otolith as described by Tzeng et al. (1997). Sr:Ca reference levels were $<1.8 \times 10^{-3}$ for freshwater residency, $>2.7 \times 10^{-3}$ for saltwater residency, and $1.8 \times 10^{-3}$ to $2.7 \times 10^{-3}$ for eels that shifted between saltwater and freshwater habitats (Lamson et al. 2006).

Eels were independently aged three times by two persons who marked the otolith annuli in years. Eels were considered to be age 0 in their year of arrival in continental waters, and year 1 was recorded as the next ring outside the elver check. (Michaud, Dutil \& Dodson 1988; Shiao, Iizuka, Chang \& Tzeng 2003). Distances from the primordium to each age marker and to the edge of the otolith were measured to $1 \mu \mathrm{m}$ along the longest axis using image analysis software (Rohlf 2004).

\section{Length-at-age}

Linear and exponential regression was used to examine the age-length and age-weight relations, respectively, of eels whose residency history was determined by $\mathrm{Sr}: \mathrm{Ca}$ analysis. As the departure timing for spawning depends on size, not age (De Leo \& Gatto 1995), fastgrowing eels depart earlier than slow-growing eels and the latter may be over-represented in higher age categories. Following Oliveira \& McCleave (2002) and Jessop et al. (2004), regression analysis was restricted to younger individuals, using a cut-off age of 14. Equality of age-length slopes was tested using ANCOVA.

To estimate length at spawning migration for saltwater residents of Brackley and Covehead Bays, length-at-age trajectories in this system were compared with the mean length of silver eels emigrating from two coastal freshwater ponds, Long and Campbells Ponds, located 2 and $4 \mathrm{~km}$, respectively, east of the study area (Cairns, Omilusik, Leblanc, Atkinson, Moore \& McDonald 2007).

\section{Back-calculation}

Length at age prior to capture was back-calculated from length-at-capture and otolith radius measurements (Francis 1990, 1995). Linear regression was used to relate fish length and otolith radius (data $\log _{10}$-transformed) in 164 eels from the BrackleyCovehead system. Coefficients from this regression were used to create the back-calculation equation under the body proportional hypothesis (BPH) (Francis 1995): $\log _{10} L_{\mathrm{i}}=\left[\left(\mathrm{c}+\mathrm{d} \times \log _{10} O_{\mathrm{i}}\right) /\left(\mathrm{c}+\mathrm{d} \times \log _{10} O_{\mathrm{c}}\right)\right] \times \log _{10} L_{\mathrm{c}}$

where $L_{\mathrm{i}}$ is the length at age, $O_{\mathrm{i}}$ the otolith radius at annulus i, $O_{\mathrm{c}}$ the otolith radius at capture, $L_{\mathrm{c}}$ the total length at capture, $\mathrm{c}$ the intercept and $\mathrm{d}$ the slope from the regression of total length on otolith radius.

Annual increment in length was estimated for each eel from age 1 to the last annual ring before the edge of the otolith by calculating the difference between length

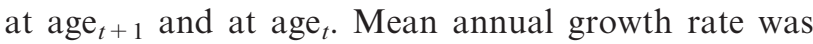
compared with the percent of continental life spent in salt water. Within-year growth rate was compared with percent of that year spent in salt water to determine if growth rate tracks habitat salinity on a year-by-year basis.

Mass of eels in years prior to capture was estimated from back-calculated lengths using a mass-length equation for eels in the southern Gulf of St. Lawrence $\left(\right.$ Mass $=0.0007006 \times$ Length $^{3.2332}, n=6341$, mass in $\mathrm{g}$ and length in $\mathrm{cm}$, Cairns et al. 2007). To adjust for individual variation in mass-at-age, body masses generated by this formula were multiplied by a correction factor $(C)$ :

$$
C=\frac{\text { mass at capture from length }- \text { weight equation }}{\text { weight measured at capture }}
$$

\section{Chlorophyll}

Mean chlorophyll $a$ concentrations of eight freshwater impoundments and 19 bays/estuaries on Prince Edward Island were derived from MacFarlane (1999), Raymond, Crane \& Cairns (2002), and PEI Dept Environment, Energy, and Forestry (2005). All chlorophyll assays were conducted in the same laboratory using the same methodology.

\section{Results}

Age was related to length in eels under 15 years using Length $=241.9+60.8 \times$ Age $\left(r^{2}=0.275, n=43\right.$, $P<0.001 ; 95 \%$ CI: $70.5-413.3$ for the intercept and 29.7-91.9 for the $x$-coordinate, lengths in $\mathrm{mm}$ ) for salt water residents (Fig. 2). The equation for freshwater residents was Length $=200.2+42.7 \times$ Age $\left(r^{2}=0.727, n=17, P<0.001 ; 95 \%\right.$ CI: 45.3-355.2 for the intercept and 28.3-57.1 for the $x$-coordinate). Saltwater residents had a significantly steeper agelength slope than freshwater residents $(t=3.74$, $P<0.001$ )

The minimum legal size in southern Gulf of St. Lawrence commercial eel fisheries is $530 \mathrm{~mm}$ and 
(a)

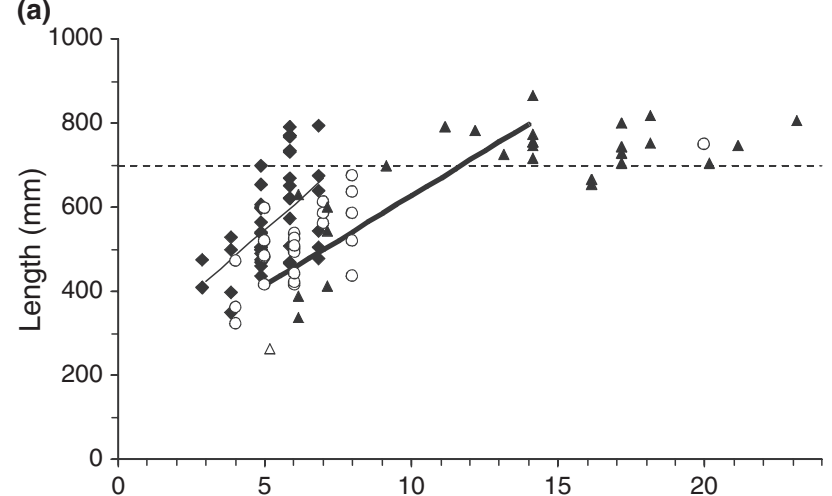

(b)

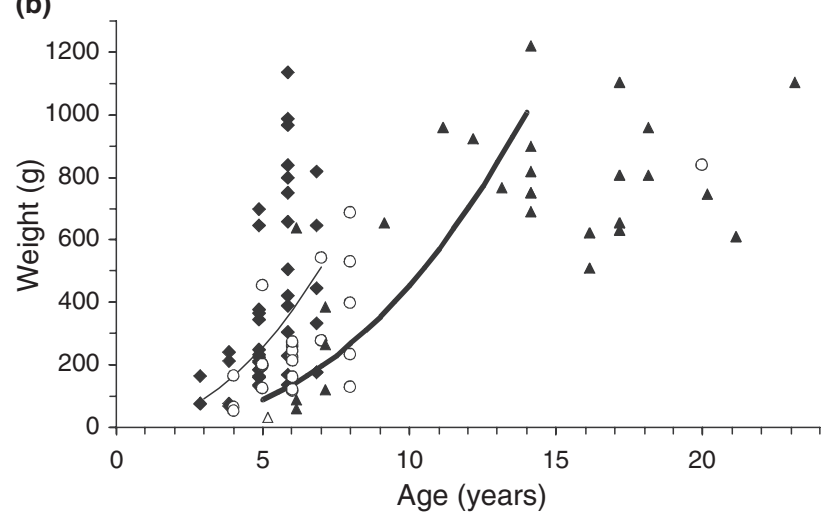

Figure 2. Length (a) and weight (b) at age of American eel salt water residents (diamonds), inter-habitat shifters (circles), and freshwater residents (triangles). Linear (a) and power (b) regression lines are shown for saltwater residents (thin lines) and freshwater residents (heavy lines). (a) The dashed line shows the mean length of silver eels emigrating from Long and Campbells Ponds (Cairns et al. 2007).

emigrating female silver eels at Long and Campbells Ponds have a mean length of $699 \mathrm{~mm}(\mathrm{SD}=54$, $n=264$; Cairns et al. 2007). Thus eels are potentially exposed to the fishery between these lengths. Based on growth rates of individual eels, mean length of time when eels were between 530 and $699 \mathrm{~mm}$ was 1.9 years $(\mathrm{SD}=0.45, n=43)$ for saltwater residents and 3.8 years $(\mathrm{SD}=0.98, n=27)$ for freshwater residents.

Age-mass relations were Mass (in g) $=9.46 \times$ $\operatorname{Age}^{2.05}\left(r^{2}=0.311, n=43, P<0.001\right)$ for salt water residents and Mass $=1.94 \times A g e^{2.37}\left(r^{2}=0.686\right.$, $n=17, P<0.001)$ for freshwater residents under 15 years. Saltwater residents had a significantly steeper log-transformed age-mass regression slope than freshwater residents $(t=3.87, P<0.001)$.

Fulton's condition factor $\left(1000000 \times\right.$ length $/$ mass $\left.^{3}\right)$ $( \pm \mathrm{SD}, n)$ was greatest for freshwater residents $(1.87 \pm 0.22,28)$, intermediate for inter-habitat shifters $(1.77 \pm 0.26,25)$ and lowest for saltwater residents $(1.69 \pm 0.30,43)$. Condition factor differed signifi- cantly among residency groups (ANOVA; $F=3.62$, $P=0.031$ ). A Bonferroni post hoc test indicated that condition factor differed significantly between saltwater and freshwater residents $(P=0.025)$ but condition factor of inter-habitat shifters did not differ significantly from either saltwater or freshwater residents.

Regressions of total length vs otolith radius showed no significant differences among saltwater residents, freshwater residents and inter-habitat shifters $(t=0.064, P=0.949)$. Therefore, data from all aged eels $(n=164)$ were pooled for the regression of total length on otolith radius (Fig. 3):

$$
\begin{aligned}
\log _{10} T L(\mathrm{~mm})= & 1.1711 \times \log _{10} \text { otolith radius }(\mathrm{mm}) \\
& +2.5641
\end{aligned}
$$

This regression provided the coefficients for the BPH back-calculation model to estimate lengths at ages for eels that underwent $\mathrm{Sr}: \mathrm{Ca}$ analysis.

Mean back-calculated length-at-age increased most rapidly in saltwater residents $\left(94.0 \mathrm{~mm} \mathrm{yr}^{-1}\right)$, less rapidly in inter-habitat shifters $\left(60.5 \mathrm{~mm} \mathrm{yr}^{-1}\right)$ and least in freshwater residents $\left(45.2 \mathrm{~mm} \mathrm{yr}^{-1}\right)$ (Table 1, Fig. 4). Rates differed significantly among groups $(F=57.8$, d.f. $=2,92, P<0.0001)$. Mass-at-age based on backcalculations also increased most rapidly in saltwater residents (Fig. 4). Between 2 and 6 years of age, annual mass increments calculated for saltwater residents were a mean of 5.3 (range 4.8-5.6) times greater than those of freshwater residents. Increments calculated for these years in inter-habitat shifters were a mean of 2.3 (range 1.3-3.1) times greater than those of freshwater residents.

Mean annual growth rate of eels under 15 years of age increased significantly with the percent of continental life spent in salt water (Fig. 5a; $F=137.5$, d.f. $=94, P<0.0001)$. Similarly, growth rates of eels

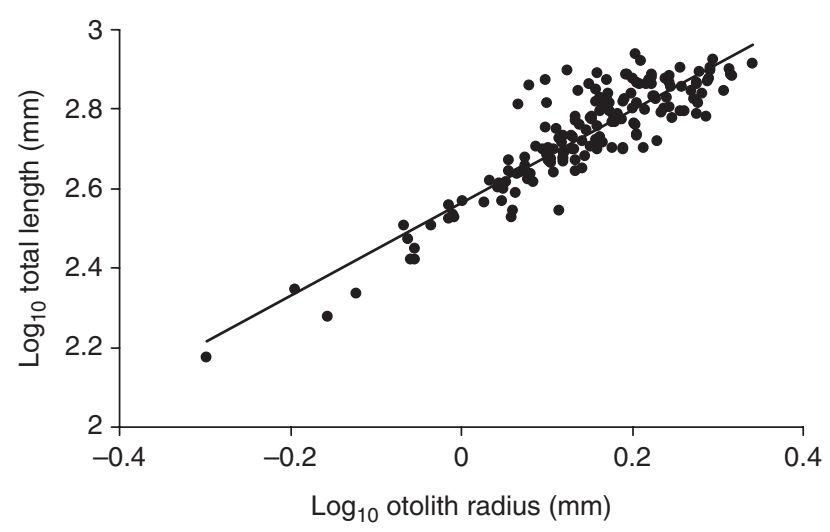

Figure 3. Relationship between total length and maximum otolith radius for American eels in the Brackley-Covehead system. 
Table 1. Mean annual growth $\left(\mathrm{mm} \mathrm{yr}^{-1}\right)$ of American eels under 15 years old, estimated by otolith radius back-calculation

\begin{tabular}{|c|c|c|c|c|c|c|c|c|c|c|c|c|c|c|c|c|c|c|c|}
\hline & \multicolumn{6}{|c|}{ Saltwater bays } & \multicolumn{10}{|c|}{ Freshwater ponds } & \multirow{3}{*}{$\frac{\text { All }}{\mathrm{SW}}$} & \multirow{3}{*}{$\begin{array}{l}\text { All } \\
\text { FW }\end{array}$} & \multirow{3}{*}{$\frac{\text { All }}{\mathrm{IH}}$} \\
\hline & \multicolumn{2}{|c|}{ Brackley } & \multicolumn{2}{|c|}{ Covehead } & \multicolumn{2}{|c|}{ Both bays } & \multirow{2}{*}{$\frac{\text { McCallums }}{\mathrm{FW}}$} & \multicolumn{3}{|c|}{ Cass } & \multicolumn{3}{|c|}{ Marshalls } & \multicolumn{3}{|c|}{ All ponds } & & & \\
\hline & SW & $\mathrm{IH}$ & SW & $\mathrm{IH}$ & SW & $\mathrm{IH}$ & & SW & FW & $\mathrm{IH}$ & SW & FW & $\mathrm{IH}$ & SW & FW & $\mathrm{IH}$ & & & \\
\hline Mean & 104.6 & 78.4 & 88.6 & 59.2 & 98.2 & 55.8 & 44.0 & 69.6 & 68.1 & 69.2 & 75.3 & 42.1 & 41.1 & 75.2 & 45.2 & 61.7 & 94.0 & 45.2 & 60.5 \\
\hline SD & 34.0 & 40.0 & 30.5 & 25.9 & 33.4 & 24.4 & 14.7 & 17.7 & 33.1 & 24.1 & 24.9 & 15.9 & 20.8 & 22.7 & 18.2 & 26.6 & 32.9 & 18.2 & 26.2 \\
\hline Number of eels & 15 & 1 & 18 & 5 & 33 & 6 & 12 & 1 & 2 & 17 & 8 & 13 & 3 & 9 & 27 & 20 & 42 & 27 & 26 \\
\hline Total eel years & 85 & 6 & 78 & 27 & 163 & 33 & 148 & 11 & 18 & 77 & 31 & 170 & 32 & 42 & 336 & 109 & 205 & 336 & 142 \\
\hline$F$-value & 2.998 & & 13.139 & & 19.866 & & & & 0.034 & & & 11.44 & & & 15.32 & & & 57.80 & \\
\hline$P$-value & 0.1053 & & 0.0016 & & 0.0001 & & & & 0.9666 & & & 0.000 & & & $<0.0001$ & & & $<0.0001$ & \\
\hline
\end{tabular}

The top two lines in the table header give sampling location.

SW, saltwater residents; IH, inter-habitat shifters; FW, freshwater residents.

$F$-values and $P$-values from linear mixed models reflect differences in annual growth between salinity residency patterns at each site and for all sites combined.

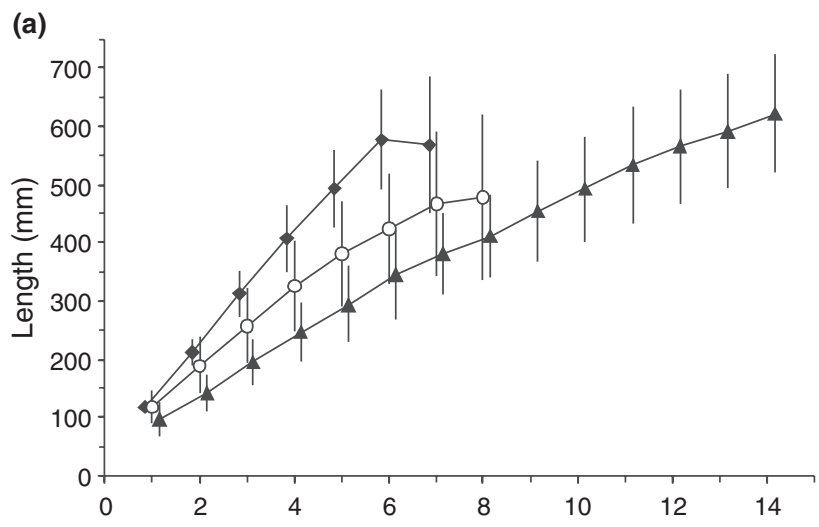

(b)

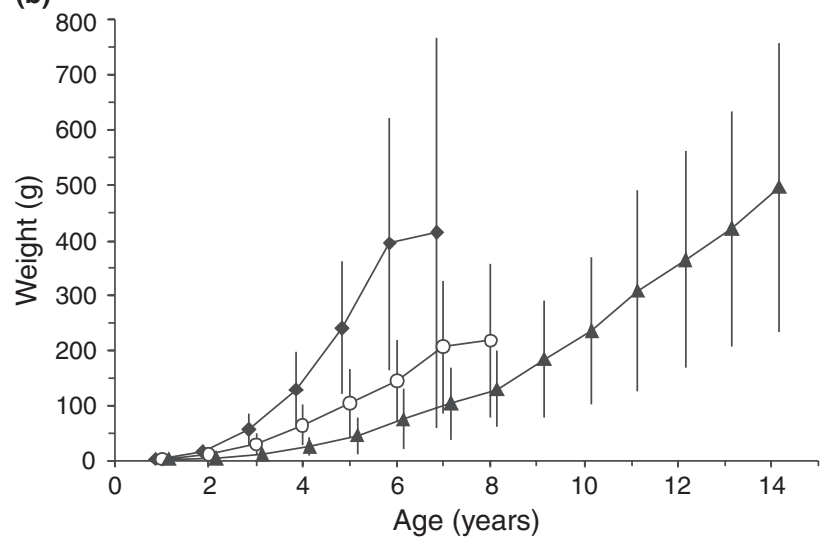

Figure 4. Mean $( \pm \mathrm{SD})$ length (a) and mass (b) at age of saltwater resident (diamonds), interhabitat shifter (circles) and freshwater resident (triangles) American eels, based on back-calculated lengths. Masses are estimated from back-calculated lengths by a length-weight formula Cairns et al. (2007), adjusted by the ratio of calculated mass:measured mass (see text).

under 15 years old during individual years increased with the percent of years spent in salt water (Fig. 5b; $F=150.9$, d.f. $=563, P<0.0001)$.
Mean chlorophyll $a$ concentrations $( \pm \mathrm{SD})$ were $4.56 \pm 2.28 \mu \mathrm{g} \mathrm{L}^{-1}$ in eight PEI freshwater ponds and $9.27 \pm 3.68 \mu \mathrm{g} \mathrm{L}^{-1}$ in 19 PEI bays and estuaries. Concentrations differed significantly between the habitat types $(F=11.1, P=0.003)$. Chlorophyll $a$ concentrations in Brackley and Covehead Bays averaged $9.60 \mu \mathrm{g} \mathrm{L}^{-1}$, close to the mean for PEI bays and estuaries.

\section{Discussion}

\section{Effects of salinity on growth and age at maturity}

This study used lengths at age, back-calculated from otolith annulus measurements, to reconstruct growth histories of American eels whose previous habitat use was determined by otolith $\mathrm{Sr}: \mathrm{Ca}$ ratios. Analysis was restricted to eels under 15 years because the departure of faster-growing eels to the spawning ground may bias the sample available for higher ages. Male eels are rare or absent in southern Gulf of St. Lawrence subpopulations (Cairns et al. 2007; Cairns, Tremblay, Caron, Casselman, Verreault, Jessop, de Lafontaine, Bradford, Verdon, Dumont, Mailhot, Zhu, Mathers, Oliveira, Benhalima, Dietrich, Hallett \& Lagacé 2008); hence eels in this study were probably all or nearly all female. Previous studies of habitat-specific growth in American eels (Cairns et al. 2004; Jessop et al. 2004; Thibault et al. 2007) found faster growth in brackish than fresh water. In this study, eels resident in salt water grew 2.2 times faster than freshwater residents, indicating that the salinity effect on growth rate extends to full-strength sea water. Differences in growth rate between the groups were significant $(P<0.001)$ despite high variability in individual growth rates that is typical of anguillid eels (De Leo \& Gatto 1995). 
(a)

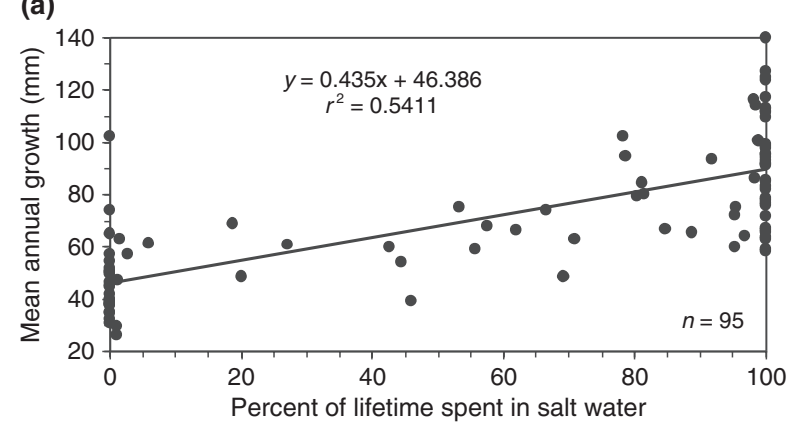

(b)

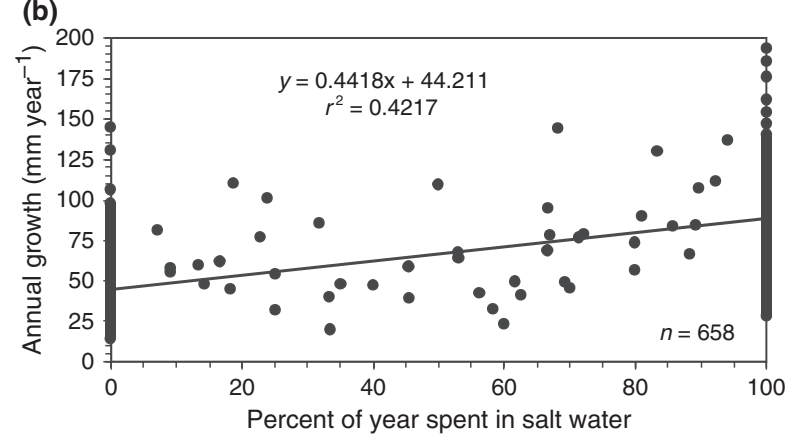

Figure 5. Growth rates of American eels under 15 years old. (a) Mean growth rate vs total time spent in salt water and (b) growth per year vs percent of that year spent in salt water.

Potential reasons for superior eel growth rates in salt and brackish water compared with fresh water include higher food availability, effects of density and crowding and inherent appetite (Cairns et al. 2009). Eels may develop behaviours that are a consistent property of the individual; e.g. salinity preferences in glass eels (Edeline \& Elie 2004) and migratory behaviours in riverine yellow eels (Feunteun, Laffaille, Robinet, Briand, Baisez, Olivier \& Acou 2003). It is thus plausible that some eels might be inherent fast-growers while others are slow-growers. However, growth increments tracked habitat salinity on the scale of individual years as well as on the scale of lifetimes (Fig. 5), suggesting that growth rate is directly linked to environmental salinity rather than to inherent characteristics of individual eels.

As yellow American eels complete their growth, they metamorphose into silver eels, which depart continental waters on their spawning migration. The timing of this metamorphosis depends on size, rather than age (De Leo \& Gatto 1995). Silver eels departing from the Brackley-Covehead system were not sampled, but silver eels leaving two nearby coastal freshwater ponds (Long and Campbells Ponds) had a mean length of $699 \mathrm{~mm}$ and a mean age of 17.8 years (Cairns et al. 2007). These values are the best available estimators of the size and age of silver eels leaving freshwater ponds in the Brackley-Covehead system. Jessop et al. (2004) found that mean size of silver eels reared in fresh waters of a Nova Scotia river did not differ significantly from mean size of those reared primarily in the brackish estuary. Mean age of silver eels reared in the salt water of Brackley and Covehead Bays, estimated from the growth equation for salt residents and the size of silver eels at Long and Campbells Ponds, was 7.5 years. It is thus estimated that freshwater residents in the Brackley-Covehead system take 17.8/7.5 $=2.4$ times longer than saltwater residents to reach the silver eel stage.

\section{Implications for conservation}

With their extended time to maturity, eels reared in fresh water have a longer period of exposure to natural mortality and to exploitation by fisheries than marinereared eels (Dekker et al. 2003). This means that annual exploitation rates in fresh water must be lower than those in marine waters to achieve an equivalent cumulative exploitation impact. Most eel fisheries in the southern Gulf of St. Lawrence are prosecuted in marine waters, and marine fisheries dominate landings in the United States (Jessop 1997; Cairns et al. 2008). However, there are extensive freshwater fisheries for yellow eels elsewhere in Atlantic Canada, Quebec and (formerly) Ontario. Salinity-based differentials in growth rate and time to maturity as reported in this and other papers underline the need for conservative management and low annual exploitation rates in these fisheries.

Notwithstanding widespread improvements in aquatic pollution levels (e.g. Hickie, Kingsley, Hodson, Muir, Béland \& Mackay 2000), Robinet \& Feunteun (2002) and Palstra, van Ginneken, Murk and van den Thillart (2006) argued that anguillid eels are highly susceptible to lipophilic contaminants that affect reproduction and early embryonic development. As these contaminants bio-accumulate during the animal's continental life, total contaminant burden will increase with duration of the continental phase. Thus, eels in fresh waters are more vulnerable to potential effects of lipophilic contaminant effects on survival and reproduction than eels that grew in marine waters because of their extended time to maturity.

American eels produced in fresh waters are also subject to silver eel fisheries and to large-scale habitat alterations by dams. Eels produced in marine waters are largely exempt from these impacts. Morrison \& Secor (2003) argued that freshwater rearing areas should be protected as unexploited reserves, and that 
eel fishing should be limited to marine habitats. Given the vulnerabilities that attend eels that rear in fresh visà-vis marine waters, such a proposal merits serious consideration.

\section{Implications for aquaculture}

Aquaculture accounts for the majority of current worldwide anguillid eel production [248 000 of $258000 \mathrm{t}(96 \%)$ in 2004, FAO 2006]. Eel culture is centred in east Asia and to a lesser extent in Europe (Lee et al. 2003). Because currently available artificial breeding techniques (Okamura, Yamada, Horie, Utoh, Mikawa, Tanaka \& Tsukamoto 2007) have not reached commercial feasibility, eel aquaculture depends on wild-caught glass eel raised in fresh water (Liao, Hsu \& Lee 2002). Eel aquaculture affects conservation of wild eels because of its need for large quantities of seed stock. Intensive eel aquaculture also causes significant environmental problems in some areas, particularly in Taiwan, where groundwater extraction for grow-out ponds has led to land subsidence and seawater ingress (Tzeng et al. 2003; Ferng 2006; Chen, Lee \& Liao 2007).

This study found that eels resident in salt water added body mass 5.3 times faster than those resident in fresh water. Superior growth in saltwater vs freshwater rearing areas is commonly attributed to higher productivity in marine habitats at temperate latitudes (Morrison \& Secor 2003; Daverat \& Tomas 2006). However, eels reared in fresh water had significantly higher condition factor than those reared in salt water, suggesting these animals are not food-stressed. In Prince Edward Island, phytoplankton-based primary productivity, as indicated by chlorophyll $a$ concentrations in marine waters was about double that in freshwater ponds (MacFarlane 1999; Raymond et al. 2002; PEI Dept Environment, Energy, and Forestry 2005). If food available to eels is correlated with primary productivity, as assumed by Gross, Coleman \& McDowall (1988), differences in chlorophyll levels can explain, some, but not all, of the superior eel growth in salt water.

Edeline \& Elie (2004) reported glass eels in tanks fed at higher rates and grew more rapidly in salt water than in fresh water, under conditions of uniform food availability. Use of salt water by fish farmers would increase mass gain at the glass eel stage, and at the yellow eel stage if salinity effects on appetite persist throughout the growth phase. More rapid growth of cultured eels would lead to faster throughput to market size, and potentially lower environmental impact per kilogram of eel produced.

\section{Conclusions}

The faster growth rates of American eel in brackish water (Jessop et al. 2008) and salt water (this study) compared with fresh water, reflects similar findings in European (Daverat \& Tomas 2006), Japanese (Tzeng et al. 2003), shortfinned (Anguilla australis, Richardson; Arai, Kotake, Lokman, Miller \& Tsukamoto 2004) and Australian longfinned eels (Anguilla reinhardtii, Steindachner; Walsh, Pease, Hoyle \& Booth 2006). Growth rates have pervasive impacts on fish demographics and life history (Roff 2002). In anguillid eels, growth rates determine when the threshold size for reproduction is reached, and therefore the duration of exposure to natural and artificial mortality. Widespread declines in worldwide anguillid eel populations have sparked calls for urgent conservation action (Dekker et al. 2003). International efforts to mitigate anthropogenic pressures on eels, including fisheries harvest, aquaculture seed stock collection, and habitat alteration (e.g. EU 2007), should recognise and embrace effects of salinity-linked growth rates on vital demographic characteristics.

\section{Acknowledgments}

Otolith analysis was supported by the National Science Council, ROC (NSC 91-2313-B-002-291 and 92-2313B-002-057). Thanks are extended to A. McLennan, C. Muttart, V.Tremblay, N. McDonald and R. Moore for assistance in the laboratory and field. R.A. Curry, T.J. Benfey, and B.M. Jessop provided valuable advice and comments.

\section{References}

Arai T., Kotake A., Lokman P.M., Miller M.J. \& Tsukamoto K. (2004) Evidence of different habitat use by New Zealand freshwater eels Anguilla australis and A. dieffenbachii, as revealed by otolith microchemistry. Marine Ecology Progress Series 266, 213-225.

Cairns D.K., Secor D.H., Morrison W.E. \& Hallett J.A. (2009) Salinity-linked growth in anguillid eels and the paradox of temperate-zone catadromy. Journal of Fish Biology. In press.

Cairns D.K., Shiao J.C., Iizuka Y., Tzeng W.N. \& MacPherson C.D. (2004) Movement patterns of American eels in an impounded watercourse, as indicated by otolith microchemistry. North American Journal of Fisheries Management 24, 452-458.

Cairns D.K., Omilusik D.L., Leblanc P.H., Atkinson E.G., Moore D.S. \& McDonald N. (2007) American eel abundance indicators in the southern Gulf of St. Lawrence. Canadian 
Data Report of Fisheries and Aquatic Sciences No. 1192, 119 pp.

Cairns D., Tremblay V., Caron F., Casselman J., Verreault G., Jessop B., de Lafontaine Y., Bradford R., Verdon R., Dumont P., Mailhot Y., Zhu J., Mathers A., Oliveira K., Benhalima K., Dietrich J., Hallett J. \& Lagacé M. (2008) American eel abundance indicators in Canada. Canadian Data Report of Fisheries and Aquatic Sciences No. 1207. $78 \mathrm{pp}$.

Casselman J.M. (2003) Dynamics of resources of the American eel, Anguilla rostrata: declining abundance in the 1990s. In: K. Aida, K. Tsukamoto \& K. Yamauchi (eds) Eel Biology. Tokyo: Springer, pp. 255-274.

Chen Y.H., Lee W.C. \& Liao I.C. (2007) Sustainable development of eel aquaculture industries in Taiwan and mainland China. In: P.S. Leung, C.S. Lee \& P.J. O’Bryen (eds) Species and System Selection for Sustainable Aquaculture. Oxford: Blackwell, pp. 295-312.

Daverat F. \& Tomas J. (2006) Tactics and demographic attributes in the European eel Anguilla anguilla in the Gironde watershed, SW France. Marine Ecology Progress Series 307, 247-257.

Daverat F., Limburg K.E., Thibault I., Shiao J.C., Dodson J.J., Caron F., Tzeng W.N., Iizuku Y. \& Wickstrom H. (2006) Phenotypic plasticity of habitat use by three temperate eel species Anguiilla anguilla, A. japonica, and A. rostrata. Marine Ecology Progress Series 308, 231-241.

De Leo G.A. \& Gatto M. (1995) A size and age-structured model of the European eel (Anguilla anguilla). Canadian Journal of Fisheries and Aquatic Sciences 52, 1351-1367.

Dekker W., Casselman J.M., Cairns D.K., Tsukamoto T., Jellyman D. \& Lickers H. (2003) Worldwide decline of eel resources necessitates immediate action. Fisheries 28(12), $1-3$.

Edeline E. \& Elie P. (2004) Is salinity choice related to growth in juvenile eel Anguilla anguilla? Cybium 28(suppl. 1), 77-82.

EU (2007) Council regulation No 1100/2007 establishing measures for the recovery of the stock of European eel. Official Journal of the European Union L248, 17-23.

FAO (2006) FAO Yearbook of Fishery Statistics. 98/2. Rome: Food and Agricultural Organization, 199 pp.

Ferng J.J. (2006) Biophysical assessments in evaluating industrial development: an experience from Taiwan freshwater aquaculture. Ecological Economics 63, 427-434.

Feunteun E., Laffaille P., Robinet T., Briand C., Baisez A., Olivier J.-M. \& Acou A. (2003) A review of upstream migration and movements in inland waters by Anguillid eels: towards a general theory. In: K. Aida, K. Tsukamoto \& K. Yamauchi (eds) Eel Biology. Tokyo: Springer, pp. 191-213.

Francis R.I.C.C. (1990) Back-calculation of fish length: a critical review. Journal of Fish Biology 36, 883-902.
Francis R.I.C.C. (1995) The analysis of otolith data A mathematician's perspective (What, precisely is your model?). In: D.H. Secor, J.M. Dean \& S.E. Campana (eds) Recent Developments in Fish Otolith Research, vol 19. Belle W. Baruch Library in Marine Science, pp. 81-95.

Gross M.R., Coleman M.R. \& McDowall R.M. (1988) Aquatic productivity and the evolution of diadromous fish migration. Science 239, 1291-1293.

Hickie B.E., Kingsley M.C.S., Hodson P.V., Muir D.C.G., Béland P. \& Mackay D. (2000) A modelling-based perspective on the past, present, and future PCB contamination of the St. Lawrence beluga whale (Delphinapterus leucas) population. Canadian Journal of Fisheries and Aquatic Sciences 57(Suppl. 1), 101-112.

Holmgren K., Wickstrom H. \& Clevestam P. (1997) Sexrelated growth of European eel, Anguilla anguilla, with focus on median silver eel age. Canadian Journal of Fisheries and Aquatic Sciences 54, 2775-2781.

Jessop B. (1997) An overview of European and American eel stocks, fisheries, and management issues. In: R.H. Peterson (ed.) The American Eel in Eastern Canada: Stock Status and Management Strategies. Canadian Technical Report of Fisheries and Aquatic Sciences 2196, 6-20.

Jessop B.M., Shiao J.C., Iizuka Y. \& Tzeng W.N. (2004) Variation in the annual growth, by sex and migration history, of silver American eels Anguilla rostrata. Marine Ecology Progress Series 272, 231-244.

Jessop B.M., Cairns D.K., Thibault I. \& Tzeng W.N. (2008) Life history of American eel Anguilla rostrata: new insights from otolith microchemistry. Aquatic Biology 1, 205-216.

Lamson H.M., Shiao J.C., Iizuka Y., Tzeng W.N. \& Cairns D.K. (2006) Movement patterns of American eels (Anguilla rostrata) between salt- and freshwater in a coastal watershed, based on otolith microchemistry. Marine Biology 149, 1567-1576.

Lee W.C., Chen Y.H., Lee Y.C. \& Liao I.C. (2003) The competitiveness of the eel aquaculture in Taiwan, Japan, and China. Aquaculture 221, 115-224.

Liao I.C., Hsu Y.K. \& Lee W.C. (2002) Technical innovations in eel culture systems. Reviews in Fishery Science 10, 433-450.

MacFarlane R.E. (1999) An evaluation of the potential impacts of some Prince Edward Island impoundments on salmonid habitat. MSc thesis, Wolfville, NS: Acadia University, $153 \mathrm{pp}$.

Michaud M., Dutil J.D. \& Dodson J.J. (1988) Determination of young American eels, Anguilla rostrata, in fresh water, based on otolith surface area and microstructure. Journal of Fish Biology 32, 179-189.

Moriarty C. (2003) The yellow eel. In: K. Aida, K. Tsukamoto \& K. Yamauchi (eds) Eel Biology. Tokyo: Springer, pp. 89-105. 
Morrison W.E. \& Secor D.H. (2003) Demographic attributes of yellow-phase American eels (Anguilla rostrata) in the Hudson River estuary. Canadian Journal of Fisheries and Aquatic Sciences 60, 1487-1501.

Okamura A., Yamada Y., Horie N., Utoh T., Mikawa N., Tanaka S. \& Tsukamoto K. (2007) Effects of water temperature on early development of Japanese eel Anguilla japonica. Fisheries Science 73, 1241-1248.

Oliveira K. \& McCleave J.D. (2002) Sexually different growth histories of the American eel in four rivers in Maine. Environmental Biology of Fishes 59, 141-151.

Palstra A.P., van Ginneken V.J.T., Murk A.J. \& van den Thillart G.E.E.J.M. (2006) Are dioxin-like contaminants responsible for the eel (Anguilla anguilla) drama? Naturwissenschaften 93, 145-148.

PEI Dept Environment, Energy, and Forestry (2005) Public water data. Available at: http://www.gov.pe.ca/envengfor/ waterdata/app.php.

Pitcher T.J. \& Hart P.J.B. (1982) Fisheries Ecology. London: Croom Helm, 414 pp.

Raymond B.G., Crane C.S. \& Cairns D.K. (2002) Nutrient and chlorophyll trends in Prince Edward Island estuaries. In: D.K. Cairns (ed.) Effects of Land Use Practices on Fish, Shellfish, and their Habitats on Prince Edward Island, Canadian Technical Report of Fisheries and Aquatic Sciences 2408, 142-153.

Richkus W.A. \& Whalen K. (2000) Evidence for a decline in the abundance of the American eel, Anguilla rostrata (LeSueur), in North America since the early 1980s. Dana 12, 83-97.
Robinet T. \& Feunteun E. (2002) Sublethal effects of exposure to chemical compounds: a cause for the decline in Atlantic eels? Ecotoxicology 11, 265-277.

Roff D.A. (2002) Life History Evolution. Sunderland, MA: Sinauer, 527 pp.

Rohlf F.J. (2004) TpsDig, Digitize Landmarks and Outlines, version 2.0. Stony Brook, NY: State University of New York.

Shiao J.C., Iizuka Y., Chang C.W. \& Tzeng W.N. (2003) Disparities in habitat use and migratory behavior between tropical eel Anguilla marmorata and temperate eel $A$. japonica in four Taiwanese rivers. Marine Ecology Progress Series 261, 233-242.

Tesch F.W. (2003) The Eel. Oxford: Blackwell Science, 408 pp. Thibault I., Dodson J.J., Caron F., Tzeng W.N., Iizuka Y. \& Shiao J.C. (2007) Facultative catadromy in the American eel: testing the conditional strategy hypothesis. Marine Ecology Progress Series 344, 219-229.

Tzeng W.N., Severin K.P. \& Wickstrom H. (1997) Use of otolith microchemistry to investigate the environmental history of European eel Anguilla anguilla. Marine Ecology Progress Series 149, 73-81.

Tzeng W.N., Iizuka Y., Shiao J.C., Yamada Y. \& Oka H.P. (2003) Identification and growth rates comparison of divergent migratory contingents of Japanese eel (Anguilla japonica). Aquaculture 216, 77-86.

Walsh C.T., Pease B.C., Hoyle S.D. \& Booth D.J. (2006) Variability in growth of longfinned eels among coastal catchments of south-eastern Australia. Journal of Fish Biology 68, 1693-1706. 